JURNAL PENDIDIKAN, p-ISSN 2715-095X, e-ISSN 2686-5041

Volume 30, No.1, Maret 2021 (113-122)

Online: http://journal.univetbantara.ac.id/index.php/jp

\title{
Peningkatan Hasil Belajar IPA Materi Peduli Terhadap Makhluk Hidup Melalui Model Example Non-Example Kelas IV SDN Telukan 03 Sukoharjo Semester 1 Tahun Pelajaran 2019/2020
}

\section{Tutik Marwiki}

\author{
Guru Kelas SDN Telukan 03 Sukoharjo, Email: tutikmarwiki14@gmail.com
}

\begin{abstract}
Abstrak: Berdasarkan pengamatan kondisi di SDN Telukan 03 Sukoharjo, terutama pada siswa kelas IV mata pelajaran IPA Peduli terhadap makhluk hidup kondisi diawal guru menggunakan metode mengajar klasikal dengan ceramah dan guru sebagai fokus pembelajarannya. hasilnya, dalam tes evaluasi ternyata sebanyak $42 \%$ dari 5 siswa atau 12 siswa masih mendapatkan nilai di bawah kriteria ketuntasan yang ditetapkan yaitu 70 sedangkan rata-rata kelas yaitu 67 masih jauh dari kriteria ketuntasan yang ditetapkan guru diawal pembelajaran. Penelitian ini bertujuan untuk mengetahui peningkatan, kenaikan persentase hasil belajar IPA materi peduli makhluk hidup melalui model example non-example. Metode penelitian yang digunakan adalah penelitian tindakan kelas dengan siklus. Data penelitian diperoleh dari ulangan harian siswa dari kondisi awal, siklus 1 dan siklus 2. Data hasil observasi berupa pengamatan baik pengamatan pada siswa maupun guru dalam penggunaan model example non-example mata pelajaran IPA Materi Peduli Terhadap Makhluk Hidup. Sumber data penelitian menggunakan data primer dan data sekunder, pengumpulan data dilakukan melalui pengamatan langsung, tes dan dokumen. Hasil penelitian diketahui bahwa "Model pembelajaran example non-example terbukti meningkatkan hasil belajar IPA Materi Peduli terhadap Makhluk Hidup Siswa Kelas IV SDN Telukan 03 Sukoharjo Semester 1 Tahun Pelajaran 2019/2020”. Persentase tuntas belajar klasikal pada kondisi awal 52\%, menjadi 100\% terjadi peningkatan siklus 2 sebesar $48 \%$.
\end{abstract}

Kata-kata Kunci: hasil belajar IPA,example non-example, model pembelajaran

\section{Improved Science Learning Outcomes for Living Materials through Non Example Example Class IV SDN Telukan 03 Sukoharjo Semester 1 Academic Year 2019/2020}

\section{Tutik Marwiki}

The Teacher of SDN Telukan 03 Sukoharjo, Email: tutikmarwiki14@gmail.com

\begin{abstract}
Based on observations of conditions at SDN Telukan 03 Sukoharjo, especially in grade IV students in science subjects Caring for living conditions at the beginning of the teacher using classical teaching methods with lectures and teachers as the focus of learning. As a result, in the evaluation test it turned out that $42 \%$ of the 5 students or 12 students still scored below the specified completeness criteria, namely 70, while the class average of 67 was still far from the completeness criteria set by the teacher at the beginning of the lesson. This study aims to determine the increase, increase in the percentage of learning outcomes in science learning material caring for living things through the non-example model. The research method used was class action research with cycles. The research data were obtained from students' daily tests from the initial conditions, cycle 1 and cycle 2. The observation data were in the form of observations of both students and teachers in using the example non example model in science subjects Caring for Living Things. Sources of research data using primary data and secondary
\end{abstract}


data, data collection is done through direct observation, tests and documents. The results of the study show that "the example non example learning model is proven to improve science learning outcomes Caring Materials for Class IV SDN Telukan 03 Sukoharjo Semester 1 Academic Year 2019/2020". The percentage of completing classical learning at the initial conditions was $52 \%$, to $100 \%$ there was an increase in cycle 2 by $48 \%$.

Keywords: Science learning outcomes, example non example, learning model

\section{Pendahuluan}

Pendidikan merupakan bagian dari sebuah pilar bangsa yang membutuhkan proses yang panjang serta dukungan dari berbagai faktor dan pihak untuk menghasilkan hasil yang berkualitas. Salah satu faktor pendukungnya adalah proses pembelajaran di sekolah. Pembelajaran dikatakan berhasil jika memberikan kebermaknaan bagi siswa. Kebermaknaan dapat terlihat apabila terjadi perubahan pengetahuan dan sikap yang positif peserta didik terhadap lingkungan. Mata pelajaran IPA bagi siswa Sekolah Dasar merupakan ilmu awal atau dasar dari pengetahuan mereka berkaitan dengan kehidupan, makhluk hidup beserta segala permasalahan yang mengikutinya, dalam menyampaikan materi pelajaran guru selalu dihadapkan dengan hal hal yang nyata atau riil. Pada kegiatan pelaksanaan pembelajaran biasanya guru hanya menyampaikan materi pokoknya saja, itupun dengan penyamapaian model lawas yaitu ceramah dengan guru sebagai fokus dan sumber belajar. Kebosanan siswa dalam menjalani proses pembelajaran, kadang kala menyebabkan turunnya prestasi belajar yang diraih. faktor terbesar penyebab kebosanan siswa adalah guru masih menggunakan model klasikal dengan ceramah dalam penyampaian materinya. Pembelajaran IPA akan sangat menarik jika dilakukan dengan melibatkan interaksi siswa dalam kegiatannya, disamping dapat meminimalisir kebosanan siswa juga diharapkan dapat meningkatkan hasil belajar siswa tersebut.Berkembangnya model pembelajaran diharapkan mampu dimanfaatkan oleh guru untuk mengembangkan proses belajar mengajar, banyak sekali metode mengajar yang bisa disajikan guru didalam kelas. Model example non-example merupakan salah satu bentuk pembelajaran yang bisa digunakan dalam mengajarkan materi Ilmu Pengetahuan Alam. Pada awal pembelajaran guru masih menggunakan metode mengajar klasikal dengan ceramah dan guru sebagai fokus pembelajarannya diperoleh hasil tes evaluasi siswa kelas IV Semester 1 SDN Telukan 03, Sukoharjo, terutama pada pada mata pelajaran IPA materi peduli terhadap makhluk hidup ternyata sebanyak $42 \%$ atau 5 siswa dari jumlah keseluruhan yaitu 12 siswa memperoleh nilai di bawah KKM yaitu 70. Persentase tuntas belajar klasikal pada kondisi awal 58\% atau 7 dari 12 siswa telah mencapai ketuntasan, sedangkan rata- rata-rata yang diharapkan oleh guru yaitu 67 sehingga perlu adanya perbaikan untuk meningkatkan nilai rata rata di dalam kelas. Nilai tertinggi yang diraih siswa baru 80 dengan 40 sebagai nilai terendah, dan masih belum memenuhi KKM yang ditetapkan guru diawal pembelajaran. Model kooperatif menerapkan kelompok-kelompok dalam anggota kecil yang beranggotakan dua sampai lima anggota yang saling bekerja bersama sama untuk meningkatkan belajar mereka dan hasil belajar masing masing anggota kelompok (Komalasari, 2010:62). Model kooperatif ini menekankan pada diskusi kelompok yang 
bertujuan untuk membuat siswa lebih aktif dalam bekerja bersama dengan kelompoknya, dimana anggotanya terdiri atas anggota kelompok yang heterogen. Menyikapi perubahan kondisi kehidupan sekarang ini, khususnya dalam dunia pendidikan saat ini, para ahli pendidikan terdorong untuk mengembangkan berbagai model pembelajaran. Model kooperatif ini menjadi acuan dalam merencanakan suatu perencanaan dalam proses kegiatan belajar. Tahapan tahapan model pembelajaran meliputi tahapan tahapan dalam kegiatan belajar mengajar, lingkungan belajar dan pengelolaan kelas (Trianto, 2007:42). Unsur-unsur model pembelajaran yang dapat meningkatkan hasil belajar secara maksimal antara lain yaitu: (1)Positive interdependence (saling membutuhkan) menunjukan bahwa model kooperatif memiliki dua tanggung jawab. Tanggung jawab pertama, mempelajari materi yang diberikan kepada setiap kelompoknya. Kedua, mempelajari tugas secara mandiri oleh masing masing anggota di dalam kelompok; (2)Personal responsibility (tanggungjawab perseorangan) akan muncul tanggung jawab di setiap diri siswa agar mencapai keberhasilan kelompok; (3) Face to face promotiveinteraction (hubungan satu dengan yang lain), dalam unsur siswa saling membutuhkan dengan kata lain ketergantungan positif, sehingga unsur satu ini sangatlah penting;(4) Interpersonal skill (komunikasi setiap anggota) dalam mengkoordinasikan kegiatan siswa hendaknya berkomunikasi secara baik dan tidak mendominasi, siswa dapat mengenal, mempercayai, saling menerima dan mendukung, serta mampu menyelesaikan permasalahan secara terukur;(5) Group processing (Proses pengelompokkan) dilakukan untuk mengetahui urutan kegiatan dari setiap kelompoknya (Agus, 2010:58).Selain mempunyai kelebihan model belajar kooperatif memiliki beberapa kelemahan yaitu adanya siswa dalam kelompok yang kurang ataupun tidak aktif, adapun kelemahan itu dapat bisa dihindari dengan cara yaitu: (1)Masing masing anggota kelompok bertanggungjawab menyelesaikan masalah bagian yang menjadi tanggungjawabnya; (2) Masing masing anggota kelompok mempelajari materi secara keseluruhan, karena masing masing anggota menyumbang skor dalam kelompoknya. (Agus, 2010:54). Adapun langkah-langkah model example non example yaitu (1) Mempersiapkan gambar-atau contoh permasalahan sesuai dengan materi; (2) Gambar tersebut bisa ditempelkan di Lembar Kerja Siswa (3) Memberi kesempatan dan petunjuk pada siswa agar memperhatikan/menganalisis permasalahan gambar tersebut; (4) Siswa mendiskusikan permasalahan yang terjadi. Siswa mendiskusikan dan menganalisis permasalahan yang nampak pada gambar kemudian dicatat di selembar kertas; (5) Masing masing kelompok mengirimkan perwakilan satu orang anggotanya melakukan presentasi ke depan; (6) Siswa anggota kelompok lain dipersilahkan untuk berkomentar atau memberi masukan kepada kelompok yang sedang tampil, Guru memberikan penjelasan materi; (7) Menarik kesimpulan (Komalasari, 2010:61-62). Model pembejaran Example non examplemerupakan model yang memakai contoh-contoh. Contoh-tersebut bisa diambil dari permasalahandiwujudkan dalam bentuk gambar sesuai dengan 12 kompetensi dasar (Kiranawati, 2007:34). Model Example non example merupakan bentuk model kooperatif yang materinya memakai contoh contoh, kasus ataupun memakai gambar. Menuruy Kusumah (2008; 45) Istilah model Example non examplemerupakan suatu model pembelajaran kooperatif menggunakan contoh-contoh dapat berupa gambar, bagan, skema yang relevan dengan kompetensi dasar (Kusumah, 2008:45). Berdasarkan beberapa pendapat diatas yang dimaksud model pembelajaran Example non examplemerupakan model pembelajarandengan cara guru menggunakan contoh atau gambar gambar yang yang sesuai dengan tujuan dari pembelajaran sehingga bisa mmebuat siswa lebih aktif, dengan cara siswa menganalisis dan berdiskusi menegenao konsep atau materi yang telah diberikan. 
Model Pembelajaran Example non examplemenggunakan media gambar dalam pembelajarannya. Pemakaian media gambar digunakan dengan maksudsupaya anak dapat menganalisis kemudian mendeskripsikan secara singkat permasalahan yang terjadi pada gambar tersebut (Rochyandi 2004:11).

Konsep yang dipelajari di luar sekolah dilakukan dengan pengamtan sehingga siswa dapat mempelajari sendiri dan menemukan konsep mereka sendiri, dalam mengajarkan definisi suatu konsep perlu menggunakan model example non example. Gambaran akan sesuatu yang akan menjadi contoh disebut dengan example, sedangkan non example memberikan gambaran akan sesuatu yang bukanlah contoh dari suatu materi yang sedang dibahas. Model example non example dianggap perlu dilakukan karena suatu definisi konsep adalah suatu konsep yang diketahui secara primer hanya dari segi definisinya daripada dari sifat fisiknya. Model example dan non examplediharapkan mampu mendorong siswa dengan cara memusatkan perhatian siswa sehinggasiswa lebih memahami dan mendalami materiyang diberikan (Rochyandi, 2004:11).Model pembelajaran exampledan non examplememberikan pengalaman nyatayang dapat membantu siswa dalam membangun konsep penting yang mendalam dan bermakna. Kerangka konsep dengan model example non example antara lain: (1) Menjelaskan sebuah karakter dari konsep baru dan melakukan generalisasi pasangan contoh dan bukan contoh sehingga tercipta karakter baru, dalam satu waktu siswa dapat memikirkan kemudian menyajikan perbedaan perbedaan dari dua daftar itu, di saat siswa masih berpikirmengenai examples dan non examples, guru bisa menanyakan kepada siswa apakahperbedaan dari kedua daftar tersebut; (2) Untuk mendorong siswa menemukan konsep baru guru bisa menyiapkan model examples dan non examples tambahan, konsep yang lebih spesifik sehingga siswa terdorong untuk melakukan analisis hipotesis; (3) Siswa dimintasaling bekerja berpasangan dalam generalisasi konsep dari example dan non example kemudian setiap pasangan mempresentasikanhasil kerjasama dalam kelompoknya untuk di diskusikan di depan kelas. Bagian penutup, siswa menginformasikan konsep baru yang telah diperoleh dalam diskusinya melalui model example dan non example. Keuntungan dari model example non exampleyaitu: (1) Siswa mempunyai satu pemikiransehingga bisa digunakan dalam memperluas pemahaman konsep yang lebih mendalam dan lebih komplek; (2) Siswa dalam proses penemuan terllibat secara langsung sehingga mendorong siswa, untuk membangun konsep dari pengalaman example non example secara meningkat; (3) Memberikan sesuatu konsep yang berlawanan pada siswa sehingga siswa dapat mengeksplorasi karakteristik dan menemukan konsep yang baru dengan mempertimbangkan bagian non example yang masih memungkinkan.Kelebihan model example non example; (1) siswa lebih kritis dalam melihat gambar; (2) Siswa dapat melihatmateri berupa contoh atau gambar; (3) Memberikan kesempatansiswa mengemukakan pendapatnya. Kekurangan model pembelajaran Example non exampleyaitu: (1) Materi disajikan dalam bentuk gambar atau contoh sehingga tidak semua materi bisa digunakan; (2) Waktu yang diperlukan lebih banyak dibanding menggunakan model yang lain sehingga membutuhkan persiapan yang lebih. Kata pembelajaran menurut Sagala (2004:45) merupakan arti dari "Instruction" yang banyak digunakan dalam bidang pendidikan di Amerika. Istilah tersebut dipengaruhi oleh aliran psikologi kognitif holistik, yang menempatkan siswa sebagai sumber dari kegiatan. 
Selain itu istilah ini juga dipengaruhi oleh perkembangan teknologi yang diasumsikan dapat mempermudah siswa mempelajari segala sesuatu lewat berbagai macam media seperti bahan cetak atau program televisi, gambar, audio dan lainnya. Dimyati dan Mudjiono (2009: 297) menyatakan bahwa pembelajaran merupakan kegiatan guru yang telah di desain dan terprogrmakan secara instruksional yang tergatung terhadap penyediaan sumber belajar sehingga membuat siswa menjadi aktif. Pengertian lain tentang pembelajaran dikemukakan oleh Sahabuddin (2007: 13) yang menyatakan pembelajaran sebagai suatu sistem kegiatan yang dilakukan untuk membimbing anak sebagai individu dan sebagai kelompok serta merangsang belajar anak agar memperoleh pengalaman belajar sehingga anak dapat berkembang mencapai kedewasaan. Berdasarkan dari pendapat para ahli tersebut, maka penulis menyimpulkan yang dimaksud dengan pembelajaran yaitu proses hubungan timbal balik antara siswa dengan siswa, siswa dengan guru, siswa dengan sumber belajar di suatu tempat belajar. Proses tersebut mencakup adanya aktivitas "acquiring and modifying knowledge, skills, strategies, beliefs, attitudes, and behaviors.'Istilah Ilmu Pengetahuan Alam atau IPA dikenal juga dengan istilah sains. Kata sains ini berasal dari bahasa Latin yaitu scientia yang berarti "saya tahu".IPA dalam bahasa Inggris, kata sains berasal dari kata science yang berarti "pengetahuan". Science kemudian berkembang menjadi natural science yang dalam Bahasa Indonesia dikenal dengan ilmu pengetahuan alam (IPA) (Djojosoediro, 2008: 3).IPA merupakan cabang pengetahuan yang berawal dari fenomena alam. IPA didefinisikan sebagai sekumpulan pengetahuan tentang objek dan fenomena alam yang diperoleh dari hasil pemikiran dan penyelidikan ilmuwan yang dilakukan dengan keterampilan bereksperimen dengan menggunakan metode ilmiah.

Berdasarkan pendapat pendapat diatas dapat disimpulkan bahawa IPA merupakan pengetahuan manusia tentang gejala-gejala alam dan kebendaan yang diperoleh dengan cara observasi, eksperimen/penelitian, atau uji coba yang berdasarkan pada hasil pengamatan manusia. Pengamatan manusia dapat berupa fakta-fakta, aturan-aturan, hukumhukum, prinsip-prinsip, teori-teori dan lain sebagainya. Hasil temuan penelitian juga dilakukan Putu Wardika (2014) menyatakan bahwa hasil belajar IPA siswa antara kelompok siswa yang belajar dengan model pembelajaran example non example dan kelompok siswa yang belajar dengan model pembelajaran konvensional menunjukan hasil yang signifikan. Olh karena itu peneliti menyusun rumusan permasalahan sebagai berikut: apakah penggunaan model example non example dapat meningkatkan hasil belajar mata pelajaran IPA pada materi peduli terhadap makhluk hidup siswa Kelas IV SDN Telukan 03, Kecamatan Grogol, Kabupaten Sukoharjo, Semester 1 Tahun Pelajaran 2019/2020; Seberapa persen prosentase peningkatan hasil belajar mata pelajaran IPA pada materi peduli terhadap makhluk hidup siswa Kelas IV SDN Telukan 03, Kecamatan Grogol, Kabupaten Sukoharjo, Semester 1 Tahun Pelajaran 2019/2020; Bagaimana model example non example tersebut bisa meningkatkan hasil belajar mata pelajaran IPA pada tema peduli terhadap makhluk hidup siswa Kelas IV semester 1 SD Negeri Telukan 03, Kecamatan Grogol, Kabupaten Sukoharjo, Tahun Pelajaran 2019/2020, sedangkan tujuan dari penelitian ini adalah meningkatkan hasil belajar mata pelajaran IPA Materi peduli terhadap makhluk hidup siswa Kelas IV SD Negeri Telukan 03, Kecamatan Grogol, Kabupaten Sukoharjo, Semester 1 Tahun Pelajaran 2019/2020; melalui penggunakan model pembelajaran example Non Example Mengetahui seberapa persen prosentase peningkatan hasil belajar IPA pada Materi peduli terhadap makhluk hidup siswa Kelas IV SD Negeri Telukan 03, Kecamatan Grogol, Kabupaten Sukoharjo, Semester 1 Tahun Pelajaran 2019/2020; Mengetahui bagaimana penggunaan model pembelajaran Example Non 
Example dapat meningkatkan hasil belajar mata pelajaran IPA Materi peduli terhadap makhluk hidup siswa Kelas IV SDN Telukan 03, Kecamatan Grogol, Kabupaten Sukoharjo, Semester 1 Tahun Pelajaran 2019/2020

\section{Metode Penelitian}

Pelaksanaan penelitian dilakukan di SDN Telukan 03 Kecamatan Grogol Kabupaten Sukoharjo pada siswa kelas IV semester 1 tahun pelajaran 2019/2020. Waktu penelitian selama 5 bulan yaitu dari Agustus 2019 sampai dengan Desember 2019. Jadwal penelitian dilakukan mulai pertemuan 1 pada siklus 1 dilaksanakan pada hari Jumat, 20 September 2019, Pertemuan 2 siklus 1 dilaksanakan pada hari, Jumat, 27 September 2019 sedangkan Pertemuan 1 pada siklus 2 dilaksanakan pada hari Jumat, 11 Oktober 2019, dan Pertemuan 2 siklus 2 dilaksanakan pada hari Jumat, 18 Oktober 2019. Seluruh siswa (12 siswa) kelas IV SDN Telukan 03, Kecamatan Grogol Kabupaten Sukoharjo pada siswa kelas IV semester 1 tahun pelajaran 2019/2020 siswa akan menjadi subjek dalam penelitian sedangkan yang menjadi objek dalam penelitian ini adalah peningkatan hasil belajar IPA materi peduli terhadap makhluk hidup siswa kelas IV SDN Telukan 03, Kecamatan Grogol, Kabupaten Sukoharjo melalui model example non-example. Data penelitian berupa hasil tes siswa dari kondisi awal, siklus 1 dan siklus 2. Data hasil observasi berupa hasil observasi kegiatan pembelajaran dengan menggunakan model example non-example mata pelajaran IPA Materi Peduli Terhadap Makhluk Hidup. Sumber data penelitian menggunakan sumber data primer yaitu data-data dari sumber pertama. Data primer memakai hasil wawancara dan pengamatan terhadap siswa SDN Telukan 03, Kecamatan Grogol Kabupaten Sukoharjo Semester I Tahun Pelajaran 2019/2020 terutama siswa kelas IV yang menjadi subjek penelitian ini, sedangkan data sekunder berupa dokumentasi foto dan hasil tes (kegiatan PBM dari prasiklus, siklus 1serta siklus 2). Penulis menggunakan teknik pengumpulan data dengan cara pengamatan, tes dan dokumen. Pengamatan atau observasi data merupakan pengumpulan data yang mencatat data tentang sikap siswa selama proses pembelajaran berlangsung. Tujuannya adalah mengamati kegiatan yang terjadi dalam proses pembelajaran selain itu juga mengamati sikap baik sikap guru dengan siswa, ataupun dengan siswa itu sendiriselain itu juga untuk mengetahui hal-hal apa saja yang harus diperbaiki, dipertahankan atau ditingkatkan pada pembelajaran selanjutnya.Teknik pengumpulan data dengan cara tes digunakan untuk mengetahui atau mengukur suatu kemampuan, dengan cara dan aturan yang sudah ditentukan. Tes evaluasi dilaksanakan pada setiap akhir siklus untuk mengetahui perolehan hasil atau nilai ulangan siswa di setiap siklusnya. Teknikdokumen yang dimaksud disini berupa daftar nilai siswa yang merangkum semua hasil evaluasi siswa di tiap siklus. Validasi data menggunakan model triangulasi. Triangulasi data dilakukan dengan cara memanfaatkan jenis sumber data yang berbeda-beda untuk menggali informasi dari suatu narasumber tertentu, dari kondisi lokasinya, dari aktivitasnya yang menggambarkan perilaku orang atau warga masyarakat, atau dari sumber yang berupa catatan atau arsip dan dokumen yang memuat catatan yang terkait data yang dimaksud peneliti.Prosedur analisisnya menggunakan model alur dari Kemmis dan Taggart yang intinya mengidentifikasi perkembangan subjek yang menjadi 
sampel dengan pembelajaran tertentu dalam kurun waktu tertentu dan dilakukan secara berulang ulang hingga berhasil. Agar memperoleh data yang akurat maka observasi perlu di lakukan. Observasi adalah pengamatan secara langsung ke objek penelitian yang berupa aktivitas manusia fenomena alam dan sebagainya, sehingga bisa melihat lebih dekat yang mejadi tujuan pengamatan Metode ini dilakukan secara langsung dengan cara mengamati kondisi fisik dan perilaku yang terjadi di tempat berlangsungnya penelitian ini, dalam rangka mengumpulkan data yang memberikan gambaran tentang situasi setempat atau social setting yang menjadi konteks penelitian Hal yang menjadi fokus pengamatan adalah sikap ilmiah siswa selama berlangsungnya kegiatan pembelajaran yang dilakukan oleh guru. Peneliti melakukan analisis dan refleksi data yang terkumpul selama kegiatan pembelajaran. Berdasarkan hasil analisis dan refleksi dijadikan bahan untukmelakukan tindakan penelitian

\section{Hasil Penelitian}

Hipotesis tindakan yang menyatakan bahwa "melalui model example non example diduga dapat meningkatkan hasil belajar mata pelajaran Ilmu Pengetahuan Alam (IPA) Materi Peduli terhadap Makhluk Hidup Siswa Kelas IV Semester 1 SDN Telukan 03, Kecamatan Grogol, Kabupaten Sukoharjo,Tahun Pelajaran 2019/2020" terbukti kebenarannya. Peningkatan nilai rata-rata ulangan dan tingkat ketuntasan pada tiap siklus dari kondisi awal sampai dengan akhir tindakan siklus 2. Kondisi awal sebelum tindakan, diketahui hasil belajar siswa cukup rendah. Hal ini ditunjukkan dengan besarnya nilai ratarata ulangan harian siswahanya67 dan tingkat ketuntasan belajar sebesar 58\%. Kondisi tersebut diindikasikan disebabkan karena proses belajar mengajar yang dirasa belum mampu membuat siswaterlibat dalam pembelajaran. Pembelajaran cenderung bersifat teacher-centered dan didominasi guru.Guna mengatasi hal tersebut maka guru berupaya melakukan perbaikan pembelajaran dengan menerapkan modelexample non example.

Model pembelajaran inimerupakan salah satu model pembelajaran yang bisamembuat siswa lebih aktif membangun pengetahuan mereka melalui proses mencari dan menemukan.Pada siklus 1 guru menerapkan model example non example, siswa terlihat aktif dalam mengkontruksi gambar dengan model example non example. Upaya perbaikan yang dilakukan guru dirasasudah cukup berhasil dalam meningkatkan hasil belajar IPA siswa IV SDN Telukan 03.Hal ini ditunjukkan dengan nilai rata-rata ulangan siswa dan tingkat ketuntasan mengalami peningkatan yang cukup signifikan. Nilai rata-rata ulangan siswa mengalami peningkatan, dari kondisi awal hanya67 menjadi 72,5 di akhir siklus 1 . Peningkatan dari kondisi awal yaitu 58\% pada kondisi awal menjadi $75 \%$ membuktikan bahwa tingkat ketuntasan siswa mengalami peningkatan di akhir sklu 1.Peningkatan tersebut dipandang belum optimal, karena tingkat penguasaan penuh secara klasikal $\geq 80 \%$. Berpijak dari kondisi tersebut maka dilakukan perbaikan pembelajaran pada tindakan Siklus 2.Perbaikan diberikan guru pada siklus 2 adalah dengan memberikan contoh sehingga anak dapat bersikap ilmiah. Langkah ini dimaksudkan untuk meningkatkan aktivitas siswa agar lebih aktif berinteraksi dan bersikap ilmiah dalam pembelajaran. Tindakan perbaikan yang diberikan oleh guru ternyata efektif dalam meningkatkan hasil belajar IPA. Hal ini menunjukkan bahwa nilai-rata-rata ulangan dan tingkat ketuntasan belajar siswa mengalami peningkatan pada tindakan Siklus II. Nilai rata-rata ulangan siswa juga mengalami peningkatan yang cukup signifikan dari 67 pada tindakan kondisi awal, pada siklus 2 nilai rata rata ulangan menjadi 79, dari kondisi awal sampai siklus 2 nilai rata rata ulangan siswa di kelas meningkat sebesar 12. Adapun pencapaia ketuntasan tiap siklusnya mengalami peningkatan,di kondisi awal pencapaian ketuntasan hanya $58 \%$, pada 
siklus 2 mengalami peningkatan 100\%, terlihat dari kondisi awal sampai siklus 2 mengalami peningkatan sebesar $42 \%$. Pencapaian Ketuntasan tiap siklus dapat dilihat dalam tabel berikut.

Tabel 1. Pencapaian Ketuntasan

\begin{tabular}{lcccc}
\hline \multirow{2}{*}{ Tahapan Siklus } & \multicolumn{2}{c}{ Ketuntasan Siswa } & \multicolumn{2}{c}{ Prosentase Ketuntasan } \\
\cline { 2 - 5 } & Tuntas & Belum Tuntas & Tuntas & Belum Tuntas \\
\hline Kondisi awal & 7 & 5 & $58 \%$ & $42 \%$ \\
\hline Siklus I & 9 & 3 & $75 \%$ & $25 \%$ \\
\hline Siklus II & 12 & 0 & $100 \%$ & $0 \%$ \\
\hline
\end{tabular}

Data di atas dapat disajikan dalam diagram ketuntasan belajar sebagai berikut.

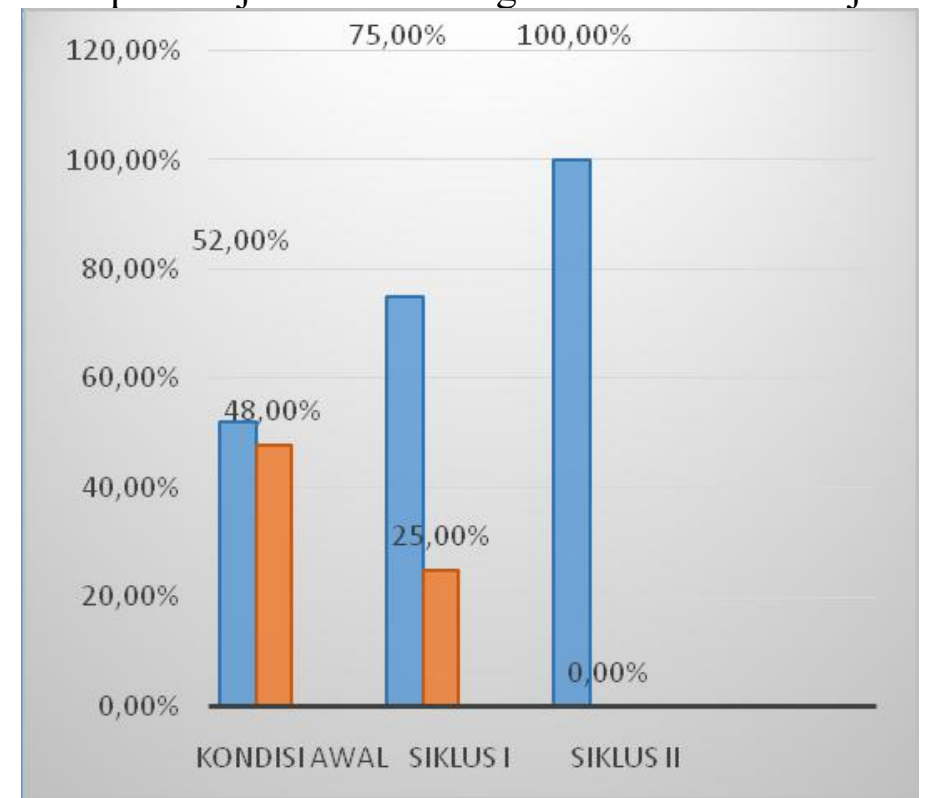

Gambar 1. Ketuntasan Belajar

Berdasarkan tabel dan gambar diatas tindakan perbaikan guru tersebut cukup efektif. Terlihat nilai rata-rata dan tingkat ketuntasan belajar siswa pada tindakan Siklus 2 mengalami peningkatan yang cukup signifikan. Hal ini ditandai dengan nilai rata-rata ulangan harian siswa dari kondisi awal adalah 69,33 pada siklus 2 diperoleh nilai rata rata ulangan harian siswa sebesar 88,00 terjadi peningkatan sebesar 18,67 Adapun ketuntasan belajar yang diperoleh dari tindakan siklus 1 sebesar 66,67, di akhir siklus 2 menjadi 100\% meningkat sebesar 33,33\% dari kondisi awal sampai siklus 2. Senada dengan penelitian dari Hadi Pranoto (2017) bahwa hasil belajar siswa kelas VI B SD Negeri Turitempel pada pembelajaran IPA dengan menggunakan model pembelajaran Examples Non Examples mengalami peningkatan dari siklus I ke siklus II.

\section{Pembahasan}


Kondisi awal tindakan merupakan hasil refleksi terhadap pencarian fakta tentang pembelajaran IPA Materi "peduli terhadap makhluk hidup" siswa kelas IV SDN Telukan 03 Kecamatan Grogol Kabupaten Sukoharjo Semester 1 tahun pelajaran 2019/2020. Data refleksi diperoleh dari pengamatan terhadap hasil tes ulangan harian siswa sebelum dilakukan tindakan pembelajaran dengan model example non example. Hasil tes diperoleh dari nilai ulangan harian yang diperoleh dari 12 orang siswa kelas IV SDN Telukan 03 Kecamatan Grogol Kabupaten Sukoharjo Semester 1, tahun pelajaran 2019/2020, dapat diketahui bahwa nilai terendah yang diperoleh adalah sebesar 40 , nilai tertinggi sebesar 80 , dan nilai rata-rata ulangan harian kelas diperoleh sebesar 67 . Nilai rata-rata yang diperoleh siswa sebesar $67<\mathrm{KKM}$ atau kriteria ketuntasan minimal yang telah ditentukan, yaitu sebesar 70,00. Atas dasar hal tersebut, maka siswa kelas IV SDN Telukan 03 Kecamatan Grogol Kabupaten Sukoharjo Semester 1 tahun pelajaran 2019/2020 secara klasikal belum memenuhi kriteria ketuntasan belajar dalam pembelajaran IPA materi peduli terhadap makhluk hidup Hipotesis tindakan yang menyatakan bahwa "Melalui model example non example diduga dapat meningkatkan hasil belajar mata pelajaran Ilmu Pengetahuan Alam (IPA) Materi Peduli terhadap Makhluk Hidup Siswa Kelas IV SDN Telukan 03 Kecamatan Grogol Kabupaten Sukoharjo, Semester 1, Tahun Pelajaran 2019/2020" terbukti kebenarannya. Hal ini ditunjukkan dengan peningkatan nilai rata-rata hasilulangan harian siswa dan tingkat ketuntasan hasil belajar pada setiap siklus tindakan yang dilakukan. Sebelum tindakan siklus, hasil belajar IPA siswa cukup rendah. Hal ini ditunjukkan dengan besarnya nilai rata-rata ulangan harian siswa sebesar 67 dan tingkat ketuntasan belajar sebesar 58\%. Kondisi tersebut diindikasikan disebabkan karena proses belajar mengajar yang belum mampu mendorong keterlibatan siswa dalam kegiatan belajarnya. Pembelajaran cenderung bersifat teacher-centered dan didominasi guru. Guna mengatasi hal tersebut guru berupaya melakukan perbaikan pembelajaran dengan menerapkan model example non example. Model pembelajaran inidapat mendorong siswa supaya aktif dan kreatif dalam membangun pengetahuan mereka melalui proses mencari dan menemukan. Penggunaan metode ini diharapkan dapat mendorong siswa untuk menemukan dan mengkonstruksipengetahuan mereka tentang suatu konsep. Tindakan Siklus 1, diperoleh rata-rata nilai ulangan siswa adalah 72,5 , Nila rata-rata yang diperoleh telah mencapai $\mathrm{KKM} \geq 70$ maka secara klasikal dikatakan siswa sudah memenuki kriteria ketuntasan belajar tersebut. Meskipun demikian, indikator penguasaan penuh secara klasikal berupa Prosentase siswa yang mememenuhi $\mathrm{KKM} \geq 70$ sebanyak $\geq 80 \%$ belum terpenuhi, baru $75 \%$ atau baru 9 siswa yang memenuhi kentuntasan sedangkan 3 siswa atau $25 \%$ belum mencapai ketuntasan. Pada akhir tindakan siklus 2, diperolehnilai rata-rata ulangan siswa pada akhir tindakan pembelajaran siklus 2 yaitu sebesar 79. Ketuntasan belajar siswa meningkat menjadi sebesar $100 \%$ pada akhir tindakan Siklus 2

\section{Simpulan dan Saran}

Berdasarkan data analisis dan pembahasan maka dapat di tarik kesimpulan bahwa melalui model example non-example diduga dapat meningkatkan hasil belajar mata pelajaran Ilmu Pengetahuan Alam (IPA) materi peduli terhadap makhluk hidup siswa kelas IV SDN Telukan 03 Kecamatan Grogol Kabupaten Sukoharjo Semester 1, Tahun Pelajaran 2019/2020 terbukti kebenarannya.Hal ini ditunjukkan dengan peningkatan hasil belajar dari kondisi awal hingga siklus 2, yaitu sebagai berikut: model pembelajaran yang digunakan dalam penelitian merupakan model pembelajaran yang membuat siswa berusaha untuk 
mencari, menemukan serta mengkonstruksi pengetahuan mereka tentang suatu konsep sehingga dapat menyelesaikan/memecahkan suatu permasalahan. Model pembelajaran example non-example terbuktimeningkatkan hasil belajar Ilmu Pengetahuan Alam (IPA) Materi Peduli terhadap Makhluk Hidup Siswa Kelas IV SDN Telukan 03 Kecamatan Grogol Kabupaten Sukoharjo Semester 1,Tahun Pelajaran 2019/2020. Persentase tuntas belajar klasikal sebelum di berikan tindakan hanya58\%, setelah adanya tindakan menjadi $100 \%$ meningkat sebesar $42 \%$. Dari perolehan data tersebut dapat disimpulkan jika model pembelajaran example non exampleterbukti meningkatkan hasil belajarIlmu Pengetahuan Alam (IPA) Materi Peduli terhadap Makhluk Hidup Siswa Kelas IV SDN Telukan 03 Kecamatan Grogol Kabupaten Sukoharjo Semester 1 Tahun Pelajaran 2019/2020 . Saran yang dapat peneliti sampaikan setelah melaksanakan perbaikan pembelajaran sebagai yaitu siswa sebaiknya meningkatkan kerja sama di dalam proses belajar, untuk guru, diharapkan guru dalam mengajarhendaknya menggunakanstrategi, metode atau model pembelajaran yang sesuai dengan materi dengan inovasi yang menyenangkan sehingga memberikan pengalaman yang lebih nyataterhadap siswa di kelasnya, diharapkan sekolah dapat menciptakan suasana sekolah yang kondusif dengan memfasilitasi sarana dan prasarana yang menunjang proses belajar di sekolah seperti kelengkapan buku, adanya teknologi yang lebih canggih seperti laptop dan lcd.

\section{Daftar Rujukan}

Agus suprijono. (2010). Cooperative Learning. Yogyakarta. Pustaka Media.

Djojosoediro, Wasih. (2008). Pengembangan dan Pembelajaran IPA SD. Bandung: Refika Aditama.

Dimyati dan Mudjiono. (2009). Strategi Belajar Mengajar. Jakarta: PT Rineka Cipta. Hadi Pranoto. (2017). Peningkatan Hasil Belajar Siswa Melalui Model Pembelajaran

Examples Non Examples Pada Mata Pelajaran IPA Siswa Kelas VI B Semester 1 SDNegeri Turitempel Tahun Pelajaran 2016/2017. Majalah Ilmiah Pendidikan Dasar. UPGRIS, Volume 7(1), hal: 43-51. https://doi.org/10.26877/malihpeddas.v7i1.1765 Kiranawati.(2007). Model Example Non-Example. Jakarta: BumiAksara.

Komalasari, Kokom. (2010). "Pembelajaran Kontekstual Konsep dan Aplikasi”. Bandung: Refika Aditama.

Kusumah, (2008).Model Pembelajaran Kooperatif Sekolah Dasar. Jogjakarta: DIVA Press.

Muslichah. (2006). Penerapan Sains Teknologi Masyarakat Dalam. Pembelajaran Sainsdi SD. Jakarta: Depdiknas

Trianto, (2007). Model-model Pembelajaran innovatif berorientasi kontruktivistik. Jakarta: Prestasi Putaka. 